\title{
Environmental Impact Assessment of Natural Radioactivity, Heavy and Major Metals in Primary Schools' Drinking Water
}

\author{
Amal Hussain Al-Ghamdi \\ Department of Physics, Faculty of Science, University of Jeddah, Jeddah, KSA \\ Email: ahg246@yahoo.com
}

How to cite this paper: Al-Ghamdi, A. H. (2019). Environmental Impact Assessment of Natural Radioactivity, Heavy and Major Metals in Primary Schools' Drinking Water. Journal of Geoscience and Environment Protection, 7, 67-78.

https://doi.org/10.4236/gep.2019.79006

Received: June 17, 2019

Accepted: September 17, 2019

Published: September 20, 2019

Copyright $\odot 2019$ by author(s) and Scientific Research Publishing Inc. This work is licensed under the Creative Commons Attribution International License (CC BY 4.0).

http://creativecommons.org/licenses/by/4.0/

\section{Open Access}

\begin{abstract}
Measurement of natural radioactivity levels of major and heavy metals concentration was carried out for water samples collected from primary schools in Jeddah city, Saudi Arabia. The estimations were done for two different age groups, children (students $7-12 \mathrm{y}$ ) and adults (teachers and workers $>17 \mathrm{y}$ ) at the schools. The chemical analysis was performed by an Inductively Coupled Plasma Optical Emission Spectrometry (ICP-OES) and a high-resolution HPGe detector was used for the natural radionuclides measurement. The obtained results for the heavy metals $(\mathrm{Fe}, \mathrm{Cu}$, and $\mathrm{Zn})$ and major and heavy elements $(\mathrm{Na}, \mathrm{K}, \mathrm{Ca}$ and $\mathrm{Mg}$ ) concentrations in all water samples did not exceed the limits of WHO, EPA and TSE-266 guidelines for drinking water. Only Pb exceeded the safe limit. Generally, heavy metals and major elements' concentrations in water samples were found decrease in sequence of $\mathrm{Ca}>\mathrm{Na}>\mathrm{Mg}>\mathrm{K}>\mathrm{Zn}>$ $\mathrm{Pb}>\mathrm{Cu}>\mathrm{Fe}$. The radioactivity concentrations of ${ }^{226} \mathrm{Ra},{ }^{232} \mathrm{Th}$ and ${ }^{40} \mathrm{~K}$ in all studied samples were below the permissible safe limit value. The total average annual effective doses of $\left({ }^{226} \mathrm{Ra}+{ }^{232} \mathrm{Th}+{ }^{40} \mathrm{~K}\right)$ radionuclides were 0.259 $\mathrm{mSv} \cdot \mathrm{y}^{-1}$ for the children and $0.112 \mathrm{mSv} \cdot \mathrm{y}^{-1}$ for adults, which are below the recommended annual dose level $1.0 \mathrm{mSv} \cdot \mathrm{y}^{-1}$ as reported by WHO (2006). The present drinking waters are high quality waters and safe in terms of natural radioactivity and the results of the $\mathrm{HQ}$ values for the individual heavy metals showed that there was no health risk for humans due to consumption of these waters.
\end{abstract}

\section{Keywords}

Heavy Metals, Major Elements, Radioactivity

\section{Introduction}

Water is an imperative matrix in environmental studies for its daily use for hu- 
man consumption and its ability to transport pollutants (Degerlier \& Karahan, 2010). The natural radionuclides $\left({ }^{226} \mathrm{Ra},{ }^{232} \mathrm{Th}\right.$ and $\left.{ }^{40} \mathrm{~K}\right)$ and heavy elements concentrations in drinking water are significant for human health. Radionuclides are present in the form of dust, particles, or molten minerals in drinking water. The existence of radionuclides in drinking water causes human internal exposure, caused by the decay of radionuclides taken into the body through the ingestion pathway (Fatima et al., 2006). The major sources of heavy metals contamination in drinking water were iron pipes used in distribution systems and the geological pollution of the region that water was originated from some of which elements have been widely implicated in human health (Öztürk \& Yilmaz, 2000). Therefore, it is important to determine background radiation levels and amounts of metal accumulation in the environment to assess the hazards associated with their intake to prevent possible risks. Radioactivity, major and heavy element rates should not exceed the permissible limits for drinking water. For this reason, the metals and natural radioactivity concentration in water have been studied by many investigators in several countries (Ali et al., 2016; Radulescu et al., 2017; Ghaderpoori et al., 2018; Parhoudeh et al., 2019). In Saudi Arabia, there are limited studies on drinking water (Al-Ghamdi, 2014; Al-Zahrani, 2016; Althoyaib \& El-Taher, 2016; Alseroury et al., 2018). According to our literature survey conducted by the researcher, there are no data found on the quality of schools' drinking water supplies in the city of Jeddah. So, this is the first study to assess the levels of background radiation, major, and heavy metals in drinking water of this area. The aim of the study is to measure the concentration of heavy metals $(\mathrm{Fe}, \mathrm{Cu}, \mathrm{Pb}$ and $\mathrm{Zn})$, major elements $(\mathrm{Na}, \mathrm{K}, \mathrm{Ca}, \mathrm{Mg})$ and natural radioactivity of ${ }^{226} \mathrm{Ra},{ }^{232} \mathrm{Th}$ and ${ }^{40} \mathrm{~K}$ in the schools' drinking water and to estimate the radiological risk resulting in the population using these waters. The estimations were done for two different age groups, children ( $7-12 \mathrm{y})$ and adults $(>17$ $y)$, these age groups represent the student $(7-12 y)$, teachers and workers $(>17$ y) at the schools. The data produced in this study will provide a reference point levels of natural radioactivity and chemical elements in the drinking water of the study area and help in setting the background information for future research on drinking water for radiological safety of humans.

\section{Material and Methods}

\subsection{Study Area}

Jeddah city is located on the Red Sea coast in the west of Saudi Arabia, 949 kilometres from the capital, Riyadh. It is situated between the latitude of $\left(21^{\circ} 32^{\prime} 32\right)$ $\mathrm{N}$, and longitude $\left(39^{\circ} 11^{\prime} 52\right) \mathrm{E}$, within an area $5460 \mathrm{~km}^{2}$. It has a population of $3,456,259$ inhabitants (Figure 1).

\subsection{Preparation of Samples}

The water samples were collected from various primary schools in all parts of Jeddah city; stretching from its north to south and from east to west. The water 


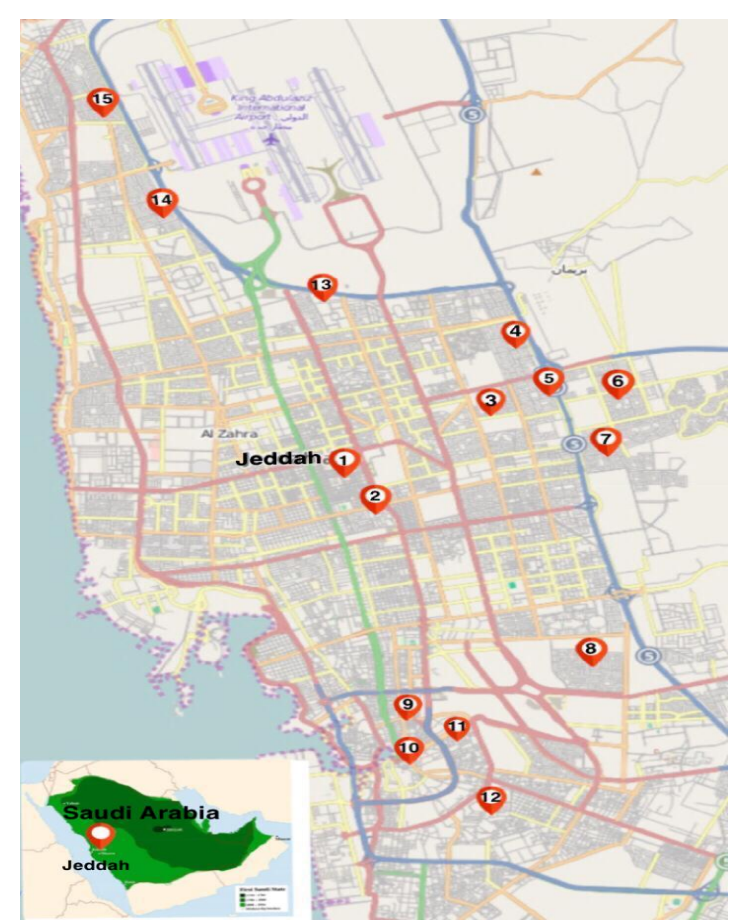

Figure 1. Locations of water samples in Jeddah city.

desalination is the source of schools' water, which is used for drinking and washing. The water samples were taken directly from the drinking water cistern and were acidified with the solution $\mathrm{HCl}$ to prevent the absorption of radionuclides on the walls of the containers (IAEA, 1989). In the laboratory, all samples were evaluated by using inductively coupled plasma optical emission spectrometry (ICP-OES) to determine the metals' ( $\mathrm{Na}, \mathrm{K}, \mathrm{Ca}, \mathrm{Mg}, \mathrm{Fe}, \mathrm{Cu}, \mathrm{Pb}$ and $\mathrm{Zn}$ ) concentrations. For the gamma measurement, Marinelli beakers were washed with distilled water. About 0.5 litres of each sample was put into a dry beaker which was sealed and stored for four weeks to ensure that the secular equilibrium had reached before the measurement was done.

\subsection{Gamma-Ray Measurements}

The gamma-ray spectra of the samples were measured using a hyper-pure germanium detector (HPGe) with 25\% efficiency and $2 \mathrm{keV}$ resolution at $1332 \mathrm{keV}$ gamma line of ${ }^{60} \mathrm{Co}$ were employed for all the measurements. The system was calibrated for energy and efficiency (IAEA, 1989). Genie 2000 computer software performed the spectrum analysis. Each sample after equilibrium was positioned on top of the HPGe detector and counted for $36000 \mathrm{~s}$. The background radiation was measured every week under the same conditions as the sample. The gamma-ray transitions of energies $351.9 \mathrm{keV}\left({ }^{214} \mathrm{~Pb}\right)$ and $609.3 \mathrm{keV}\left({ }^{214} \mathrm{Bi}\right)$ were used to determine the concentration of the ${ }^{226} \mathrm{Ra}$ series. The gamma-ray lines at the $911.1 \mathrm{Kev}\left({ }^{228} \mathrm{Ac}\right), 238.63 \mathrm{keV}\left({ }^{212} \mathrm{~Pb}\right)$ and $583.1 \mathrm{keV}\left({ }^{208} \mathrm{Tl}\right)$ were used to verify the concentration of the ${ }^{232} \mathrm{Th}$ series. ${ }^{40} \mathrm{~K}$ activities were estimated from gamma-peaks $1460.8 \mathrm{keV}$. 
The activity levels for the natural radionuclides in the measured samples were computed using the following relation (El-Taher, 2012):

$$
A\left(\mathrm{~Bq} \cdot \mathrm{L}^{-1}\right)=C_{a} / \varepsilon P_{r} V
$$

where $\mathrm{A}$ is the activity of the radionuclide in $\mathrm{Bq} \cdot \mathrm{L}^{-1}, C_{a}$ the counts per second, $\varepsilon$ the detection absolute efficiency at a specific $\gamma$-ray energy and $P_{r}$ the emission probability of Gamma-decay, and V is the volume of the water sample in a litre.

\section{Results and Discussion}

\subsection{Major and Heavy Metal Concentrations in Water Samples}

Table 1 contains the heavy metal's concentration results and the comparison with the recommended values of the World Health Organization (WHO, 2006), United States Environmental Protection Agency (EPA, 2002), and Turkish Standards Annual Progress Report (TSE-266, 1997). The elemental concentrations are expressed in Milligrams per litre. For the major elements, the results indicate that $\mathrm{Na}$ varied from $3.96 \mathrm{mg} \cdot \mathrm{L}^{-1}$ in sample w14 to $64.3 \mathrm{mg} \cdot \mathrm{L}^{-1}$ in sample w5 with a mean value of $10.48 \mathrm{mg} \cdot \mathrm{L}^{-1}$. The maximum values of $\mathrm{K}$ and $\mathrm{Ca}$ were found in the sampling code w5 $\left(3.39 \mathrm{mg} \cdot \mathrm{L}^{-1}\right.$ and $\left.25.4 \mathrm{mg} \cdot \mathrm{L}^{-1}\right)$, while their minimum values were measured in the sampling code $\mathrm{w} 7$ as $0.361 \mathrm{mg} \cdot \mathrm{L}^{-1}$ and 7.9 $\mathrm{mg} \cdot \mathrm{L}^{-1}$ in the sample code w15, respectively, with the corresponding mean values of $0.74 \mathrm{mg} \cdot \mathrm{L}^{-1}$ and $16.26 \mathrm{mg} \cdot \mathrm{L}^{-1}$ for $\mathrm{K}$ and $\mathrm{Ca}$, respectively. Although the concentration of $\mathrm{Mg}$ varied from $0.672 \mathrm{mg} \cdot \mathrm{L}^{-1}$ in sample w6 to $2.9 \mathrm{mg} \cdot \mathrm{L}^{-1}$ in sample w9 with a mean value of $1.57 \mathrm{mg} \cdot \mathrm{L}^{-1}$, the results were much lower than the maximum acceptable concentrations of $\mathrm{Na}\left(175 \mathrm{mg} \cdot \mathrm{L}^{-1}\right), \mathrm{K}\left(12 \mathrm{mg} \cdot \mathrm{L}^{-1}\right), \mathrm{Ca}$ (200 mg. $\left.\mathrm{L}^{-1}\right)$ and $\mathrm{Mg}\left(50 \mathrm{mg} \cdot \mathrm{L}^{-1}\right)$, reported by TSE-266 as shown in Table 1. For heavy elements $\mathrm{Fe}, \mathrm{Cu}$ and $\mathrm{Zn}$ ranged between 0.0153 - $0.0216 \mathrm{mg} \cdot \mathrm{L}^{-1}, 0.0525$ $0.0656 \mathrm{mg} \cdot \mathrm{L}^{-1}$ and $0.0466-0.139 \mathrm{mg} \cdot \mathrm{L}^{-1}$, respectively. The maximum and minimum values of both $\mathrm{Fe}$ and $\mathrm{Cu}$, for the water samples were found in the samples w5 and w15, respectively.

Table 1 shows that the mean elemental contractions in the water samples were $0.018,0.059$ and $0.089 \mathrm{mg} \cdot \mathrm{L}^{-1}$ for $\mathrm{Fe}, \mathrm{Cu}$ and $\mathrm{Zn}$, respectively. These results were below the guideline values as tabulated in Table 1 . The highest concentration of heavy metals was found for $\mathrm{Pb}$ element, it ranged from 0.039 to 0.081 $\mathrm{mg} \cdot \mathrm{L}^{-1}$ with a mean value $\left(0.061 \mathrm{mg} \cdot \mathrm{L}^{-1}\right)$. All the samples' concentration and the mean value were exceeding the recommended values of (WHO, 2006; EPA, 2002). The concentration of lead in drinking waters rises mainly through anthropogenic activities, and it accumulates in the body mostly in the bones. For that fact, it may cause damage to nervous system and intellectual performance for children and it can also escalate blood pressure and the cardiovascular diseases in adults (EEC, 2001). Therefore, the investigated water samples are unsafe for drinking purposes and are not suitable for life-long human consumption. Heavy metals concentration and major elements $\left[\mathrm{mg} \cdot \mathrm{L}^{-1}\right]$ in water samples under investigation were shown in Figure 2 and Figure 3, respectively. 
Table 1. Major and heavy metal concentrations in water samples with the guidelines limits.

\begin{tabular}{|c|c|c|c|c|c|c|c|c|}
\hline \multirow{2}{*}{$\begin{array}{l}\text { Sample } \\
\text { code }\end{array}$} & \multicolumn{4}{|c|}{$\begin{array}{c}\text { Major metal concentration } \\
{\left[\mathrm{mg} \cdot \mathrm{L}^{-1}\right]}\end{array}$} & \multicolumn{4}{|c|}{$\begin{array}{l}\text { Heavy metals concentration } \\
\qquad\left[\mathrm{mg} \cdot \mathrm{L}^{-1}\right]\end{array}$} \\
\hline & $\mathrm{Na}$ & K & $\mathrm{Ca}$ & $\mathrm{Mg}$ & $\mathrm{Fe}$ & $\mathrm{Cu}$ & $\mathrm{Pb}$ & $\mathrm{Zn}$ \\
\hline $\mathrm{W} 1$ & 7.11 & 0.451 & 15.3 & 0.818 & 0.0179 & 0.0619 & 0.0811 & 0.137 \\
\hline W2 & 9.54 & 0.62 & 14.7 & 1.38 & 0.0214 & 0.0633 & 0.0731 & 0.139 \\
\hline W3 & 5.4 & 0.438 & 21.6 & 0.971 & 0.021 & 0.0649 & 0.075 & 0.118 \\
\hline W4 & 5.47 & 0.436 & 25.4 & 1.24 & 0.02 & 0.0632 & 0.0711 & 0.12 \\
\hline W5 & 64.3 & 3.39 & 22.1 & 7.33 & 0.0216 & 0.0656 & 0.0801 & 0.0466 \\
\hline W6 & 5.86 & 0.551 & 19.7 & 0.672 & 0.0176 & 0.0595 & 0.0616 & 0.0803 \\
\hline W7 & 4.57 & 0.361 & 18.2 & 0.986 & 0.0174 & 0.0596 & 0.0592 & 0.0808 \\
\hline W8 & 5.08 & 0.447 & 22.2 & 0.995 & 0.0185 & 0.0592 & 0.061 & 0.0737 \\
\hline W9 & 22.7 & 1.55 & 9.79 & 2.9 & 0.0178 & 0.0583 & 0.0609 & 0.0776 \\
\hline W10 & 6.34 & 0.516 & 17.1 & 1.17 & 0.0168 & 0.0575 & 0.0562 & 0.0735 \\
\hline W11 & 4.71 & 0.387 & 22 & 1.01 & 0.0168 & 0.0572 & 0.0561 & 0.0698 \\
\hline W12 & 5.14 & 0.488 & 8.9 & 1.07 & 0.0159 & 0.0548 & 0.0478 & 0.073 \\
\hline W13 & 4.6 & 0.543 & 9.84 & 0.905 & 0.016 & 0.0555 & 0.0488 & 0.0705 \\
\hline W14 & 3.96 & 0.384 & 9.06 & 0.887 & 0.0157 & 0.0538 & 0.0461 & 0.0747 \\
\hline W15 & 7.74 & 0.549 & 7.9 & 1.14 & 0.0153 & 0.0525 & 0.0392 & 0.114 \\
\hline Mean & 10.84 & 0.74 & 16.26 & 1.57 & 0.018 & 0.059 & 0.061 & 0.089 \\
\hline WHO2006 & 200 & - & - & - & 0.3 & 2 & 0.01 & -- \\
\hline EPA2002 & - & - & - & - & 0.3 & 1.3 & 0.015 & 5 \\
\hline $\begin{array}{c}\text { TSE-266 } \\
1997\end{array}$ & 175 & 12 & 200 & 50 & 0.2 & 3 & - & 5 \\
\hline
\end{tabular}

\subsection{Hazard Quotient}

The Risk of the heavy metals through ingestion may be characterized using the following equation (Zhuang et al., 2009):

$$
H Q=A D D / R f D
$$

where $R f D$ (milligrams per kilogram per day) is the reference dose, its values of all the measured heavy metals were taken from US-EPA (1993). $A D D$ (milligrams per kilogram of body weight per day) is the average daily dose and it was determined by the following equation (Zhuang et al., 2009):

$$
A D D=C_{\text {metal }} \times W / m
$$

where $C_{\text {metal }}$ is the concentration of heavy metals in water sample; $\mathrm{W}$ is the average daily consumption of water (2 litres for adults), as given by UNSCEAR (2000); $\mathrm{m}$ is the body weight of $70 \mathrm{~kg}$ for adults. If $H Q>1.00$, there is a highly possible risk associated with that metal.

Result of health risk assessments $(H Q)$ of the various heavy metals considered in this study is presented in Table 2. The HQ ranges from $0.001(\mathrm{Fe})$ to 0.486 


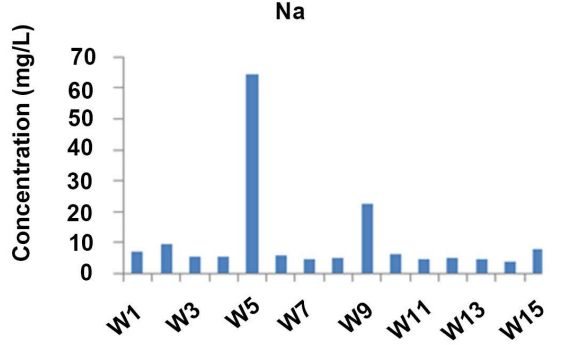

Samples

$\mathrm{Ca}$

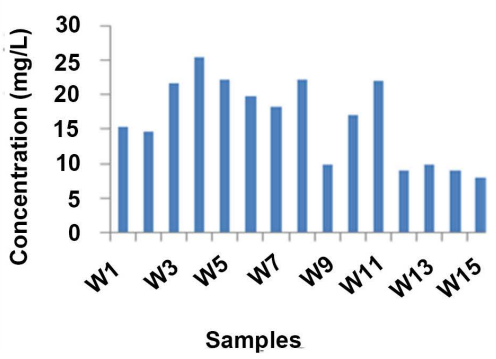

$\mathrm{K}$

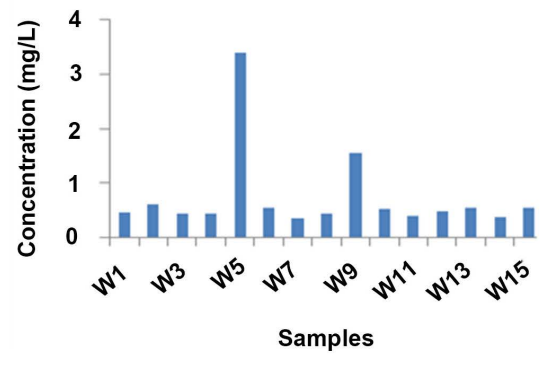

Mg

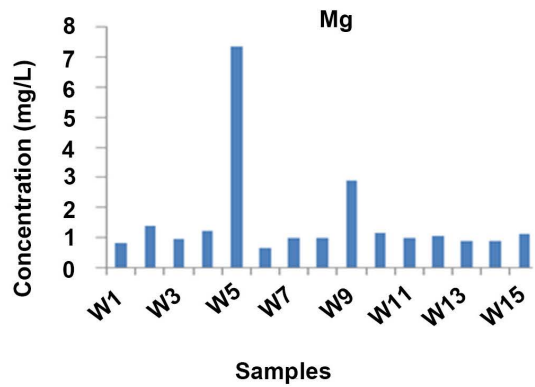

Figure 2. Major metal concentration $\left[\mathrm{mg} \cdot \mathrm{L}^{-1}\right]$ in water samples under investigation.
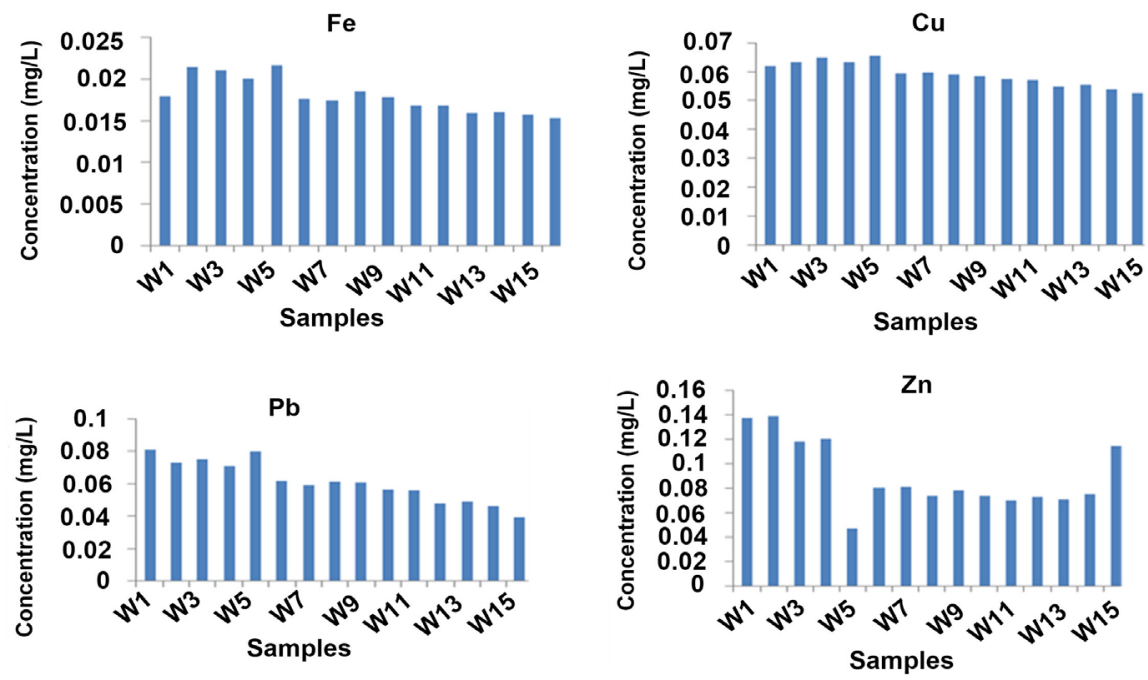

Figure 3. Heavy metal concentration $\left[\mathrm{mg} \cdot \mathrm{L}^{-1}\right]$ in water samples under investigation.

$(\mathrm{Pb})$. All the HQ values were below the critical value of 1 as reported by the US-EPA. Even though the concentration of $\mathrm{Pb}$ in the drinking water samples was found above the limit set by (WHO, 2006; EPA, 2002). This metal does not pose a risk to human health, where the HQ was calculated for $\mathrm{Pb}$ was 0.486 , below the recommended limit. But there is the need for a continuous monitoring of contamination level of this metal in schools' drinking water since it can accumulate to toxic level. It will help to detect any change in it accumulation pattern that could become a hazard to human safety. Generally, HQs were less than 1, indicating that there is no significant potential health risk associated with the consumption of these waters. 
Table 2. ADDs and HQs of heavy metals in drinking water samples.

\begin{tabular}{cccc}
\hline Metals & $\begin{array}{c}R f D \\
(\mathrm{mg} / \mathrm{kg} \text { body weight/day })\end{array}$ & $\begin{array}{c}A D D \\
(\mathrm{mg} / \mathrm{kg} \text { body weight/day })\end{array}$ & $\begin{array}{c}H Q \\
\text { (Hazard Quotient })\end{array}$ \\
\hline $\mathrm{Fe}$ & $7 \times 10^{-1}$ & 0.0005 & 0.0007 \\
$\mathrm{Cu}$ & $4.0 \times 10^{-2}$ & 0.0017 & 0.0049 \\
$\mathrm{~Pb}$ & $3.5 \times 10^{-3}$ & 0.0017 & 0.486 \\
$\mathrm{Zn}$ & $3.0 \times 10^{-1}$ & 0.0025 & 0.0085 \\
\hline
\end{tabular}

\subsection{Activity Concentrations}

The activity concentration of the three radionuclides ${ }^{226} \mathrm{Ra},{ }^{232} \mathrm{Th}$ and ${ }^{40} \mathrm{~K}$ for the investigated drinking water were reported in Table 3. As shown, the activity concentrations of ${ }^{226} \mathrm{Ra}$ ranged from $0.087 \pm 0.03$ to $0.434 \pm 0.05 \mathrm{~Bq} \cdot \mathrm{L}^{-1}$ with an average of $0.28 \mathrm{~Bq} \cdot \mathrm{L}^{-1}$, it was not detected in three samples (W3, W7 \& w13). ${ }^{232} \mathrm{Th}$ concentration ranged from $0.038 \pm 0.02$ to $0.186 \pm 0.05 \mathrm{~Bq} \cdot \mathrm{L}^{-1}$ with an average $0.085 \mathrm{~Bq} \cdot \mathrm{L}^{-1}$ and for ${ }^{40} \mathrm{~K}$ concentrations changed from $1.43 \pm 0.073$ to 12.19 $\pm 0.586 \mathrm{~Bq} \cdot \mathrm{L}^{-1}$ with an average $5.24 \mathrm{~Bq} \cdot \mathrm{L}^{-1}$.

${ }^{40} \mathrm{~K}$ is the most abundant concentration in the water samples, it can be noted that, potassium- 40 is an isotope of critical element; it is controlled by the human cells. So, the body content of ${ }^{40} \mathrm{~K}$ is verified largely by its physiological characteristics rather than its intake (Jibiri et al., 2007). It is obvious through the present work that all results are less than the limit given in the report WHO (2006), as shown in Table 3 and Figure 4. A comparison between the measured activity concentration values of ${ }^{226} \mathrm{Ra},{ }^{232} \mathrm{Th}$ and ${ }^{40} \mathrm{~K}$ in the present work with the results for local and other countries was tabulated in Table 4. We can indicate that the obtained average concentrations of ${ }^{226} \mathrm{Ra}\left(0.32 \mathrm{~Bq} \cdot \mathrm{l}^{-1}\right),{ }^{232} \mathrm{Th}\left(0.12 \mathrm{~Bq} \cdot \mathrm{l}^{-1}\right)$ and ${ }^{40} \mathrm{~K}$ $\left(5.24 \mathrm{~Bq} \cdot \mathrm{l}^{-1}\right)$ are comparable with the reported values of drinking water from various locations in the world, taking into account the data of the countries of different geographical locations differ regarding specific mineral.

\subsection{Effective Dose}

Effective doses due to ingestion of waters were determined using the following equation (UNSCEAR, 2000):

$$
E_{d}=A_{c} A_{i} C_{f}
$$

where $E_{d}$ the effective dose $\left(\mathrm{mSv} \cdot \mathrm{y}^{-1}\right), A_{c}$ is the activity concentration $\left(\mathrm{Bq} \cdot \mathrm{L}^{-1}\right), \mathrm{A}_{\mathrm{i}}$ is the consumption rate of water (1/year). According to WHO (2006), the dose was estimated by considering a consumption rate is 7301 /year for adults and 512 1/year for children. The dose conversion factors $C_{f}$ for adults and children were $\left(2.8 \times 10^{-7}, 2.3 \times 10^{-7}, 6.2 \times 10^{-9}\right.$ and $\left.1.5 \times 10^{-6}, 2.5 \times 10^{-7}, 7.6 \times 10^{-9} \mathrm{~Sv} \cdot \mathrm{Bq}^{-1}\right)$ for

${ }^{226} \mathrm{Ra},{ }^{232} \mathrm{Th}$ and ${ }^{40} \mathrm{~K}$ respectively (WHO, 2006; ICRP-60, 1990).

Table 5 shows the maximum and minimum values of effective dose of ${ }^{226} \mathrm{Ra}$, ${ }^{232} \mathrm{Th}$, and ${ }^{40} \mathrm{~K}$ for children and adults were below the reported range $(0.2-0.8$ $\mathrm{mSv} \cdot \mathrm{y}^{-1}$ ) of effective dose from ingestion of drinking water reported by 
Table 3. Activity concentrations of ${ }^{226} \mathrm{Ra},{ }^{232} \mathrm{Th}$ and ${ }^{40} \mathrm{~K}$ radionuclides from drinking water samples collected from primary schools in Saudi Arabia, Jeddah city.

\begin{tabular}{|c|c|c|c|}
\hline \multirow{2}{*}{ Sample code no. } & \multicolumn{3}{|c|}{ Activity concentration $\left(\mathrm{Bq} \cdot \mathrm{L}^{-1}\right)$} \\
\hline & ${ }^{226} \mathrm{Ra}$ & ${ }^{232} \mathrm{Th}$ & ${ }^{40} \mathrm{~K}$ \\
\hline W1 & $0.283 \pm 0.03$ & $0.076 \pm 0.04$ & $2.38 \pm 0.133$ \\
\hline W2 & $0.194 \pm 0.02$ & $0.124 \pm 0.03$ & $8.54 \pm 287$ \\
\hline W3 & $0.292 \pm 0.02$ & N.D & $1.43 \pm 0.073$ \\
\hline W4 & $0.501 \pm 0.03$ & $0.095 \pm 0.02$ & $2.24 \pm 0.709$ \\
\hline W5 & $0.213 \pm 0.05$ & $0.172 \pm 0.02$ & $1.90 \pm 0.105$ \\
\hline W6 & $0.358 \pm 0.03$ & $0.211 \pm 0.03$ & $4.23 \pm 0.341$ \\
\hline W7 & $0.087 \pm 0.03$ & N.D & $3.32 \pm 0.175$ \\
\hline W8 & $0.434 \pm 0.05$ & $0.142 \pm 0.02$ & $5.38 \pm 0.276$ \\
\hline W9 & $0.302 \pm 0.02$ & $0.023 \pm 0.04$ & $5.07 \pm 0.266$ \\
\hline W10 & $0.236 \pm 0.04$ & $0.186 \pm 0.05$ & $6.17 \pm 0.323$ \\
\hline W11 & $0.087 \pm 0.03$ & $0.075 \pm 0.02$ & $12.19 \pm 0.586$ \\
\hline W12 & $0.162 \pm 0.02$ & $0.068 \pm 0.02$ & $10.92 \pm 0.510$ \\
\hline W13 & $0.324 \pm 0.14$ & N.D & $7.44 \pm 0.368$ \\
\hline W14 & $0.361 \pm 0.12$ & $0.062 \pm 0.02$ & $2.16 \pm 0.073$ \\
\hline W15 & $0.357 \pm 0.03$ & $038 \pm 0.02$ & $4.91 \pm 0.246$ \\
\hline Range & $\begin{array}{c}0.194 \pm 0.02- \\
0.434 \pm 0.05\end{array}$ & $\begin{array}{c}0.023 \pm 0.04- \\
0.186 \pm 0.05\end{array}$ & $\begin{array}{c}1.43 \pm 0.073- \\
12.19 \pm 0.586\end{array}$ \\
\hline Average & 0.28 & 0.085 & 5.24 \\
\hline WHO2006 & 1 & 0.1 & 10 \\
\hline
\end{tabular}

N.D.: Not detected.

Table 4. Comparison of measurement results of activity concentrations of ${ }^{226} \mathrm{Ra},{ }^{232} \mathrm{Th}$ and ${ }^{40} \mathrm{~K}$ in drinking water from various countries.

\begin{tabular}{|c|c|c|c|c|c|}
\hline \multirow{2}{*}{ Country } & \multirow{2}{*}{ Water source } & \multicolumn{3}{|c|}{ Activity concentration $\left(\mathrm{Bq} \cdot \mathrm{L}^{-1}\right)$} & \multirow{2}{*}{ Reference } \\
\hline & & ${ }^{226} \mathrm{Ra}$ & ${ }^{232} \mathrm{Th}$ & ${ }^{40} \mathrm{~K}$ & \\
\hline Saudi Arabia & Drinking water & $\begin{array}{c}1.94-0.434 \\
(0.28)\end{array}$ & $\begin{array}{c}0.023-0.186 \\
(0.085)\end{array}$ & $\begin{array}{c}1.43-12.19 \\
(5.24)\end{array}$ & Present work \\
\hline Saudi Arabia & $\begin{array}{l}\text { Bottled drinking } \\
\text { water }\end{array}$ & $\begin{array}{c}0.21-2.25 \\
(0.77)\end{array}$ & $\begin{array}{c}0.37-0.232 \\
(1.3)\end{array}$ & $\begin{array}{c}0.24-33.74 \\
\quad(11.1)\end{array}$ & (Al-Ghamdi, 2014) \\
\hline Saudi Arabia & Drinking water & $\begin{array}{c}0.105-0.568 \\
(0.32)\end{array}$ & $\begin{array}{c}0.016-0.382 \\
(0.12)\end{array}$ & $\begin{array}{c}2.16-18.84 \\
(10.96)\end{array}$ & (Al-Zahrani, 2016) \\
\hline Turkey & $\begin{array}{c}\text { Bottled } \\
\text { drinking water }\end{array}$ & $\begin{array}{c}0.517-1.22 \\
(0.78)\end{array}$ & $\begin{array}{c}0.232-1.87 \\
(1.05)\end{array}$ & $\begin{array}{c}1.54-2.57 \\
(2.19)\end{array}$ & (Kabadayi \& Gümüş, 2011) \\
\hline Malaysia & Bottled mineral water & $\begin{array}{c}0.41-0.56 \\
(0.46)\end{array}$ & $\begin{array}{c}0.34-0.99 \\
(0.54)\end{array}$ & $\begin{array}{c}2.88-7.65 \\
(4.05)\end{array}$ & (Priharti et al., 2015) \\
\hline Pakistan & Drinking water & 1.09 & 0.55 & 16.17 & (Mashiatullah et al., 2016) \\
\hline Malaysia & Bottled mineral water & $1.45-3.30$ & $0.65-3.39$ & $21.12-25.31$ & (Khandaker et al., 2017) \\
\hline Egypt (Assiut city) & Drinking water & $\begin{array}{c}0.019-0.492 \\
(0.203)\end{array}$ & $\begin{array}{c}0.015-0.351 \\
(0.081)\end{array}$ & $\begin{array}{c}0.050-2.255 \\
\quad(0.688)\end{array}$ & (El-Gamal et al., 2019) \\
\hline Iran & Drinking water & $(0.57)$ & $(0.98)$ & $(6.42)$ & (Parhoudeh et al., 2019) \\
\hline
\end{tabular}


Table 5. Annual effective dose due to the intake of natural radionuclides ${ }^{226} \mathrm{Ra},{ }^{232} \mathrm{Th}$ and ${ }^{40} \mathrm{~K}$ in the present drinking water.

\begin{tabular}{cccc}
\hline \multirow{2}{*}{ Radionuclide } & \multicolumn{2}{c}{ Annual effective dose (mSv/y) } \\
\cline { 3 - 4 } & Minimum & Children & Adults \\
\hline${ }^{226} \mathrm{Ra}$ & Maximum & 0.067 & 0.018 \\
& Average & 0.275 & 0.102 \\
& Minimum & 0.215 & 0.057 \\
${ }^{232} \mathrm{Th}$ & Maximum & 0.005 & 0.004 \\
& Average & 0.027 & 0.035 \\
& Minimum & 0.024 & 0.031 \\
${ }^{40} \mathrm{~K}^{22}$ & Maximum & 0.007 & 0.006 \\
& Average & 0.529 & 0.616 \\
& Total average annual effective dose & 0.020 & 0.024 \\
\hline
\end{tabular}

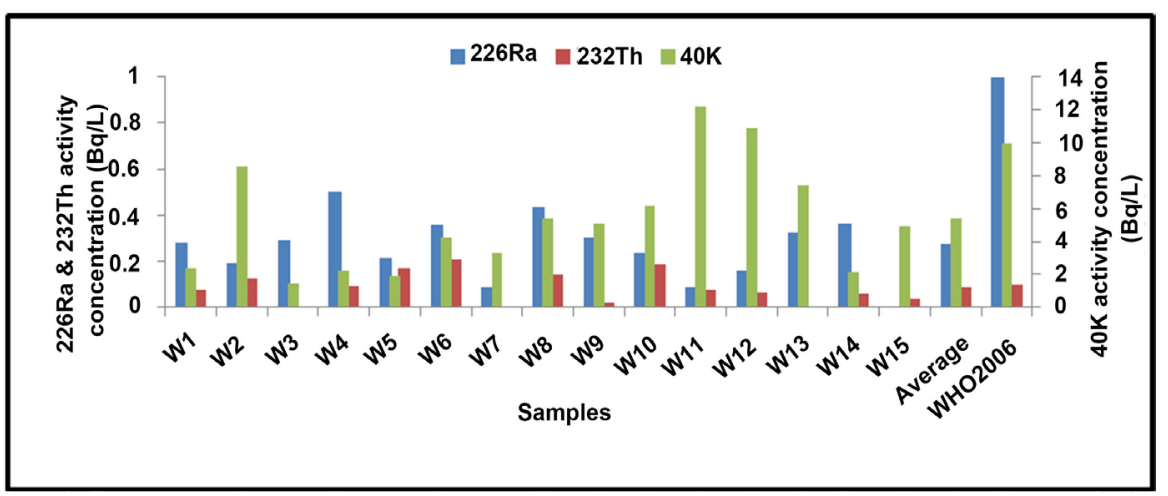

Figure 4. Activity concentrations of ${ }^{226} \mathrm{Ra},{ }^{232} \mathrm{Th}$ and ${ }^{40} \mathrm{~K}$ in water samples, Saudi Arabia.

UNSCEAR (2000). The total average annual effective doses of $\left({ }^{226} \mathrm{Ra}+{ }^{232} \mathrm{Th}+\right.$ ${ }^{40} \mathrm{~K}$ ) radionuclides were $0.259 \mathrm{mSv} \cdot \mathrm{y}^{-1}$ for the children and $0.112 \mathrm{mSv} \cdot \mathrm{y}^{-1}$ for adults, which are below the recommended annual dose level $1.0 \mathrm{mSv} \cdot \mathrm{y}^{-1}$ as reported by WHO (2006). It turned out that the overall dose consumed by children is higher than that received by adults and $226 \mathrm{Ra}$ causes the major dose. In fact, ${ }^{226} \mathrm{Ra}$ is known as an extremely radiotoxic radionuclide; the ingestion radium is saved in growing bones, therefore children have a higher risk factor because of their intensive bone growth during these years, and action must be taken to restrict their ingestion (Fatima et al., 2006). The inputs of average dose of ${ }^{226} \mathrm{Ra},{ }^{232} \mathrm{Th}$ and ${ }^{40} \mathrm{~K}$ to the total annual effective dose due to the intake of the drinking water samples were for children $(82 / 97 \%, 9.15 \% \& 7.88 \%)$ and $(51.06 \%$, $27.74 \% \& 21.21 \%$ ), respectively for adults as illustrated in Figure 5 . The total effective dose from a year's consumption of water samples by the children and adults were estimated, respectively, to be $25.9 .2 \%$ and $11.2 \%$ of the WHO limit value $1 \mathrm{mSv} \cdot \mathrm{y}^{-1}$ Consequently, it can be recommended that the present drinking water samples will not cause any radiological health detriment and be acceptable for human consumption. 


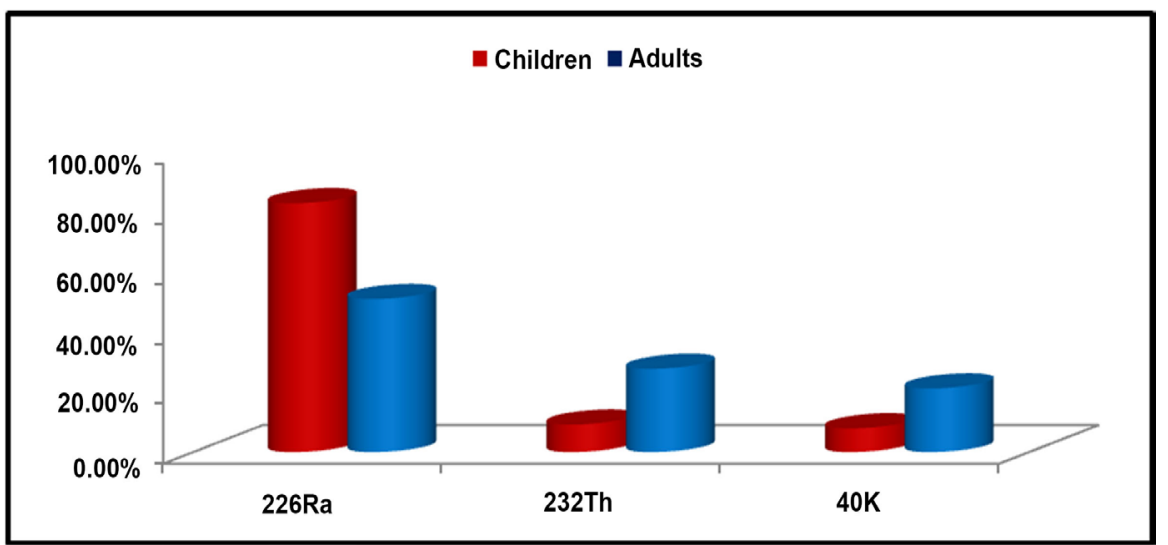

Figure 5. Percentage contribution dose of ${ }^{226} \mathrm{Ra},{ }^{232} \mathrm{Th}$ and ${ }^{40} \mathrm{~K}$ to the total effective dose in the water samples.

\section{Conclusion}

The natural radioactivity levels of ${ }^{226} \mathrm{Ra},{ }^{232} \mathrm{Th}$ and ${ }^{40} \mathrm{~K}$ and some chemical metals $(\mathrm{Na}, \mathrm{K}, \mathrm{Ca}, \mathrm{Mg}, \mathrm{Fe}, \mathrm{Cu}, \mathrm{Pb}$ and $\mathrm{Zn}$ ) were determined in drinking water collected from primary schools in Jeddah city, Saudi Arabia. The activity concentrations of the three radionuclides in the water samples were found to be within the recommended values. It is found that total averages of effective doses due to all radionuclides were 0.259 and $0.112 \mathrm{mSv} \cdot \mathrm{y}^{-1}$ for the children and adults, respectively, which were $25.9 \%$ and $11.2 \%$ of the WHO accepted limit values of 1.0 $\mathrm{mSv}$ from one year's consumption of drinking water for children and adults, respectively. As a result, it can be stated that none of the radioactivity is supposed to cause major health problems to human beings. The achieved outcomes showed that the heavy and major metals ( $\mathrm{Fe}, \mathrm{Cu}, \mathrm{Pb}, \mathrm{Zn}, \mathrm{Na}, \mathrm{K}, \mathrm{Ca}$ and $\mathrm{Mg}$ ) concentrations in all water samples did not exceed the WHO, EPA and TSE-266 standards. Only $\mathrm{Pb}$ concentration in all water samples exceeded both the limit of (WHO, 2006; EPA, 2002) guidelines. In general, the obtained HQ values for the individual metals showed that there was no health risk for humans due to the consumption of these waters. Therefore, it can be recommended that the present study discloses the fact that the investigated waters can be used as drinking water. However, water-treatment is highly suggested in order to minimize the $\mathrm{Pb}$ concentration in water sources to make the water drinkable and used directly. Regular monitoring of the radionuclides and the metals in drinking water is crucial to avoid the excessive build-up of the metals in these waters. Finally, the handiness of data from this study is very valuable as it serves as critical information concerned with the quality of drinking water. It complements data needed for setting of guidelines on radiological safety for drinking water globally.

\section{Acknowledgements}

A special thank to Syeda Bukhari for helping in proofreading and organizing the paper. 


\section{Conflicts of Interest}

The author declares no conflicts of interest regarding the publication of this paper.

\section{References}

Al-Ghamdi, A. H. (2014). Activity Concentrations in Bottled Drinking Water in Saudi Arabia and Consequent Dose Estimates. Life Science Journal, 11, 771-777.

Ali, M. M., Ali, M. L., Islam, M. S., \& Rahman, M. Z. (2016). Preliminary Assessment of Heavy Metals in Water and Sediment of Karnaphuli River, Bangladesh. Environmental Nanotechnology, Monitoring \& Management, 5, 27-35. https://doi.org/10.1016/j.enmm.2016.01.002

Alseroury, F. A., Almeelbi, T., Khan, A., Barakata, M. A., Al-Zahrani, J. H., \& Alali, W. (2018). Estimation of Natural Radioactive and Heavy Metals Concentration in Underground Water. Journal of Radiation Research and Applied Sciences, 11, 373-378. https://doi.org/10.1016/j.jrras.2018.07.004

Althoyaib, S. S., \& El-Taher, A. (2016). Natural Radioactivity Levels of Radon, Radium and the Associated Health Effects in Drinking Water Consumed in Qassim Area, Saudi Arabia. Journal of Environmental Science and Technology, 9, 208-213. https://doi.org/10.3923/jest.2016.208.213

Al-Zahrani, J. H. (2016). Risk Assessment Due to Ingestion of Natural Radionuclides and Heavy Metals in Drinking Water. International Journal of Development Research, 6, 8039-8044.

Degerlier, M., \& Karahan, G. (2010). Natural Radioactivity in Various Surface Waters in Adana, Turkey. Desalination, 261, 126-130. https://doi.org/10.1016/j.desal.2010.05.020

EEC (2001). Commission Regulation (EC) No 466/2001 of 8 March 2001 Setting Maximum Levels for Certain Contaminants in Foodstuffs. Official Journal of the European Communities, L77, 1-13.

El-Gamal, H., Sefelnasr, A., \& Salaheldin, G. (2019). Determination of Natural Radionuclides for Water Resources on the West Bank of the Nile River, Assiut Governorate, Egypt. Water, 11, 311. https://doi.org/10.3390/w11020311

El-Taher, A. (2012). Assessment of Natural Radioactivity Levels and Radiation Hazards for Building Materials used in Qassim Area, Saudi Arabia. Romanian Journal of Physics, 57, 726-735.

EPA (2002). National Primary Drinking Water Regulations (Vol. 19). Washington DC: USEPA.

Fatima, I., Zaidi, J. H., Arif, M., \& Tahir, S. N. A. (2006). Measurement of Natural Radioactivity in Bottled Drinking Water in Pakistan and Consequent Dose Estimates. Radiation Protection Dosimetry, 123, 234-240. https://doi.org/10.1093/rpd/ncl093

Ghaderpoori, M., Kamarehie, B., Jafari, A., Ghaderpoury, A., \& Karami, M. A. (2018). Heavy Metals Analysis and Quality Assessment in Drinking Water-Khorramabad City, Iran. Data in Brief, 16, 658-692. https://doi.org/10.1016/j.dib.2017.11.078

IAEA (1989). International Atomic Energy Agency. Measurement of Radiation in Food and the Environment. Guidebook. Technical Report Series No. 295, Vienna: IAEA.

ICRP-60 (1990). Recommendations of the International Commission on Radiological Protection. Oxford: Pergamon Press.

Jibiri, N. N., Farai, I. P., \& Alausa, S. K. (2007). Activity Concentrations of 226Ra, 228Th, and $40 \mathrm{~K}$ in Different Food Crops from a High Background Radiation Area in Bitsichi, 
Jos Plateau, Nigeria. Radiation and Environmental Biophysics, 46, 53-59.

https://doi.org/10.1007/s00411-006-0085-9

Kabadayi, Ö., \& Gümüş, H. (2011). Natural Activity Concentrations in Bottled Drinking Water and Consequent Doses. Radiation Protection Dosimetry, 150, 532-535. https://doi.org/10.1093/rpd/ncr430

Khandaker, M. U., Nasir, N. L. M., Zakirin, N. S., Kassim, H. A., Asaduzzaman, K., Bradley, D. A., Hayyan, A. et al. (2017). Radiation Dose to the Malaysian Populace via the Consumption of Bottled Mineral Water. Radiation Physics and Chemistry, 140, 173-179. https://doi.org/10.1016/j.radphyschem.2017.01.018

Mashiatullah, A., Maryam, B., Asma, M., Yaqoob, N., Robab, U. E., \& Ghaffar, A. (2016). Activity Concentration and Dose Estimation of 226Ra, 232Th, 40K and 137Cs in Drinking Water of Selected Areas of Punjab, Pakistan. Water Science and Technology: Water Supply, 16, 253-262. https://doi.org/10.2166/ws.2015.135

Öztürk, N., \& Yilmaz, Y. Z. (2000). Trace Elements and Radioactivity Levels in Drinking Water near Tunçbilek Coal-Fired Power Plant in Kütahya, Turkey. Water Research, 34, 704-708. https://doi.org/10.1016/S0043-1354(99)00168-2

Parhoudeh, M., Khoshgard, K., Zare, M. R., \& Ebrahiminia, A. (2019). Natural Radioactivity Level of 226Ra, 232Th, and 40K Radionuclides in Drinking Water of Residential Areas in Kermanshah Province, Iran Using Gamma Spectroscopy. Iranian Journal of Medical Physics, 16, 98-102.

Priharti, W., Samat, S. B., \& Yasir, M. S. (2015). Measurement of Natural Radionuclides in Malaysian Bottled Mineral Water and Consequent Health Risk Estimation. AIP Conference Proceedings, 1678, Article ID: 040012. https://doi.org/10.1063/1.4931269

Radulescu, I., Calin, M. R., Ion, I., Ion, A. C., Capra, L., \& Simion, C. A. (2017). Gross Alpha, Gross Beta and Gamma Activities in Bottled Natural Mineral Water from Romania. Romanian Reports in Physics, 69, 710.

TSE-266 (1997). The Institution of Turkish Standards, Annual Progress Report.

UNSCEAR (2000). United Nations Scientific Committee on the Effects of Atomic Radiation. Sources and Effects of Ionizing Radiations. New York: United Nations.

US-EPA (1993). Carcinogenicity Assessment. IRIS (Integrated Risk Information System), 2003, Washington DC: US Environmental Protection Agency.

WHO (2006). Guidelines for Drinking-Water Quality. First Addendum to the Third Edition, Recommendations (Vol. 1, p. 595). Geneva: WHO.

Zhuang, P., McBride, M. B., Xia, H., Li, N., \& Li, Z. (2009). Health Risk from Heavy Metals via Consumption of Food Crops in the Vicinity of Dabaoshan Mine, South China. Science of the Total Environment, 407, 1551-1561.

https://doi.org/10.1016/j.scitotenv.2008.10.061 